
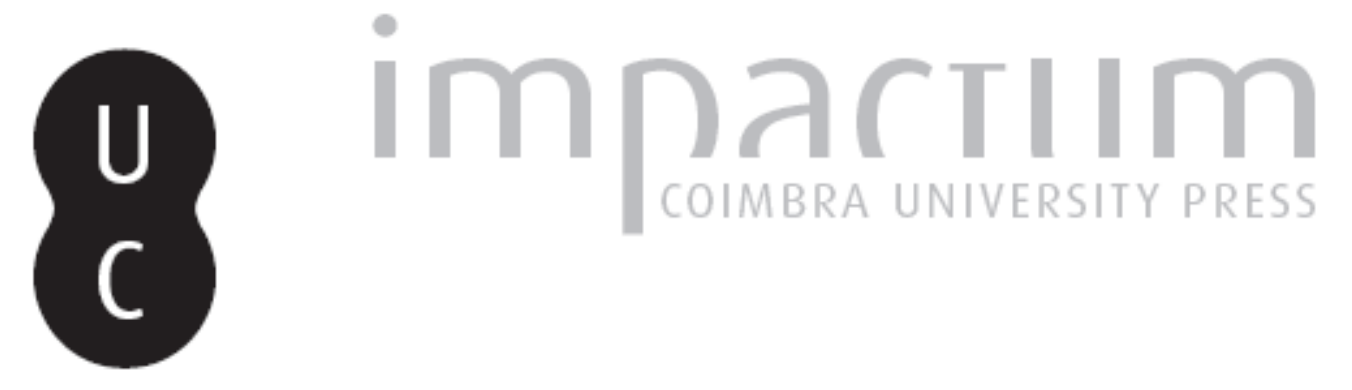

\title{
A civilidade na Pérsia aos olhos dos portugueses de Quinhentos
}

Autor(es): Jesus, Roger Lee Pessoa de

Publicado por: Centro de História da Sociedade e da Cultura

URL persistente:

URI:http://hdl.handle.net/10316.2/39517

DOI:

DOI:http://dx.doi.org/10.14195/1645-2259_10-1_7

Accessed : $\quad$ 26-Apr-2023 13:12:18

A navegação consulta e descarregamento dos títulos inseridos nas Bibliotecas Digitais UC Digitalis, UC Pombalina e UC Impactum, pressupõem a aceitação plena e sem reservas dos Termos e Condições de Uso destas Bibliotecas Digitais, disponíveis em https://digitalis.uc.pt/pt-pt/termos.

Conforme exposto nos referidos Termos e Condições de Uso, o descarregamento de títulos de acesso restrito requer uma licença válida de autorização devendo o utilizador aceder ao(s) documento(s) a partir de um endereço de IP da instituição detentora da supramencionada licença.

Ao utilizador é apenas permitido o descarregamento para uso pessoal, pelo que o emprego do(s) título(s) descarregado(s) para outro fim, designadamente comercial, carece de autorização do respetivo autor ou editor da obra.

Na medida em que todas as obras da UC Digitalis se encontram protegidas pelo Código do Direito de Autor e Direitos Conexos e demais legislação aplicável, toda a cópia, parcial ou total, deste documento, nos casos em que é legalmente admitida, deverá conter ou fazer-se acompanhar por este aviso.

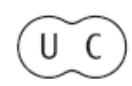




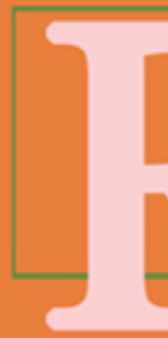

\section{evista de História}

da Sociedade e da

Cultura

\section{Tomo I}

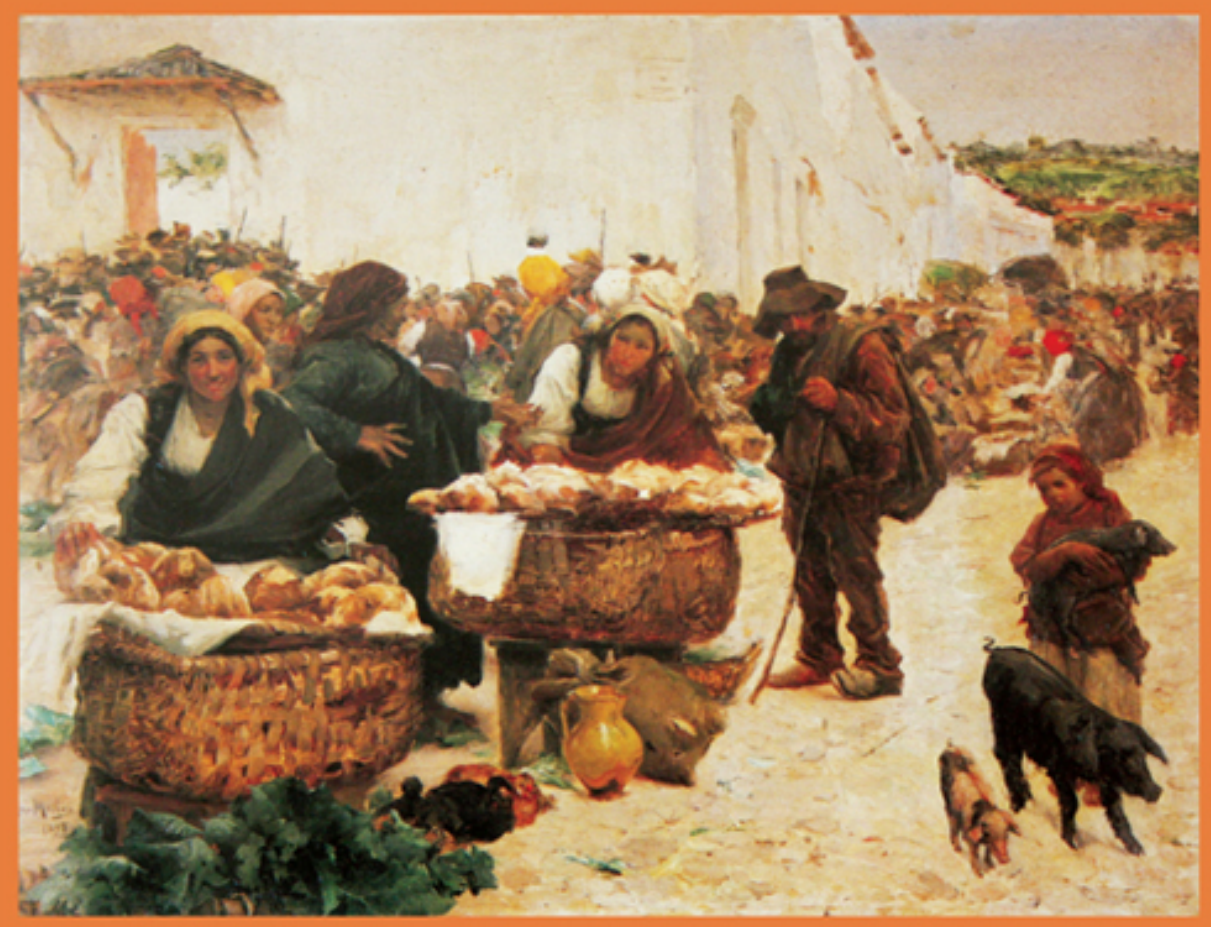

Centro de História da Sociedade e da Cultura Universidade de Coimbra

Coimbra 


\title{
A Civilidade na Pérsia aos olhos dos Portugueses de Quinhentos*
}

\author{
Roger Lee Pessoa de Jesus \\ Mestrando em História Moderna - Universidade de Coimbra \\ rogerlee.pj@gmail.com \\ Texto recebido em/ Text submitted on: 28/02/2010 \\ Texto aprovado em/ Text approved on: 22/05/2010
}

\section{Resumo/Abstract:}

Pretende-se, neste estudo, recolher os vestígios de "civilidade" (conforme a caracterizou Norbert Elias na sua obra O processo civilizacional) na Pérsia do século XVI. Partindo dos relatos das embaixadas portugueses às terras do Xeque Ismael, observaram-se vários costumes e ritos, diferentes e novos aos olhos dos portugueses. A Expansão Portuguesa possibilitou o contacto com novas sociedades e novas culturas, abrindo novos horizontes para o processo civilizacional europeu. Este estudo pretende ser, em última análise, uma reflexão, através das fontes, acerca da visão portuguesa do Oriente.

This study envisages to collect the signs of "civility" (as Norbert Elias called it) in $16^{\text {th }}$ century Persia. Based on the reports of the Portuguese missions to the land of Sheik Ismael, several customs and rituals - different and new in the Portuguese eyes - were observed. The Portuguese Expansion fostered the contact with new societies and cultures, hereby opening up the European civilisational process to new horizons. This study aims ultimately at providing - through its sources - a reflection of Portuguese views on the East.

Palavras chave/Keywords:

Expansão Portuguesa; Pérsia; Oriente; Civilidade.

Portuguese Expansion; Persia; East; Civilisation.

* Este estudo corresponde, na sua essência, ao trabalho realizado no seminário «A Civilidade nos Costumes aos Olhos dos Portugueses de Quinhentos», da licenciatura em História, orientado pelo Professor Doutor João Marinho dos Santos. Agradecemos a ajuda e o apoio dado pela Ana Rita Rocha, Joel Sabino, Ricardo Alexandre Rodrigues e da D. Conceição França do Instituto de História da Expansão Ultramarina da FLUC, na preparação desta versão. 


\author{
Vimos tambem levantar \\ sem ninguem, senon por si, \\ o Xeque Ismael Sophi, \\ e por amor ajuntar \\ gente mais que nunca ouvi: \\ deste mais atento fallo, \\ duzentos mil de cavallo \\ tras, e muytos Reys consigo, \\ he dos seus tão grão amigo, \\ que o mais que he muyto callo \\ Garcia de Resende, Miscelânea
}

A primeira viagem de Vasco da Gama à Índia abriu um mundo totalmente novo aos portugueses. Habituados a lidarem com os negros da costa ocidental africana, a frota não estava preparada para encontrar uma economia tão desenvolvida $^{2}$ e uma sociedade tão diferente. A perplexidade perante o outro é facilmente registada no relato atribuído a Álvaro Velho, ou nas obras posteriores de Tomé Pires e de Duarte Barbosa.

Esses novos comportamentos e costumes foram registados tendo por base o olhar europeu e o padrão civilizacional que emergia nessa época: a civilidade 3 . Os portugueses que nos deixaram escritos sobre o Oriente observavam com grande curiosidade as práticas correntes nesses territórios e a Pérsia não escapou a esses olhares, bem pelo contrário, tendo em conta a grandiosidade do poder do Xeque Ismael ${ }^{4}$. Pretendemos, assim, abordar a civilidade na Pérsia, nos inícios do século XVI.

Considerando a existência de várias descrições de viagens pela Pérsia, decidimos fixar-nos nas três primeiras décadas do séc. XVI. Além dos escritos dos "embaixadores" portugueses, usámos frequentemente as Crónicas de João de Barros e Gaspar Correia. Os estudos sobre a presença portuguesa

1 RESENDE, Garcia de - «Miscelânea» in Crónica de D. João II e miscelânea. Lisboa: Imprensa Nacional-Casa da Moeda, 1991, p. 338.

2 Veja-se SANTOS, João Marinho dos - As economias do Índico aquando da chegada dos portugueses. Revista Portuguesa de História. 27 (1992) 203-214.

3 Como adiante veremos, seguimos este conceito tal como foi estudado e interpretado por Nobert Elias (1897-1990) na sua obra Über den Prozess der Zivilisation (O processo civilizacional).

4 Tendo em conta a disparidade relativa aos nomes persas e portugueses para pessoas, lugares e títulos, optámos por seguir a denominação proveniente das fontes portuguesas. Em todo o caso, os títulos de Xeque, Xá, Sufi cognominam sempre o monarca do Império Persa. 
na Pérsia (especialmente no Golfo Pérsico) têm vindo a desenvolver-se ao longo dos últimos anos 5 , bem como a problemática da relação com o "outro"6.

Pretendemos encontrar os pontos de ligação entre a civilidade europeia, que os portugueses levavam, e a cultura persa, bastante diferente. Para atingir este objectivo, além da breve análise à conjuntura da época (abordando a situação política da Pérsia no século XVI) e às relações estabelecidas com Portugal, tentámos observar algumas vivências persas: o banquete e o estar à mesa, a violência e a insegurança, a corte como centro difusor (ou não) de civilidade...

\section{A Pérsia no século XVI}

De remotas origens, o gigantesco Império Persa renovou-se e afirmou-se na era de Quinhentos sob o signo de uma nova dinastia: a dos Safávidas. Pela mão de um carismático líder, o Xeque Ismael (ou Shah Isma'il, proclamado em 1500), a Pérsia uniu-se sob o impulso do xiismo. Reconhecidos pelo seu turbante vermelho, os Qizilbash (os «cabeças vermelhas»), seguidores da irmandade criada pelos Safávidas nos finais do séc. XII, espalharam o terror e, a partir da figura do novo líder, empreenderam um novo ciclo de conquistas que culminou com a subjugação de todo o território persa ao poder do grande Sufi ${ }^{7}$.

A questão do xiismo viria a ser fundamental, já que criaria um cisma profundo face aos otomanos sunitas. A questão religiosa foi, portanto, a principal razão das violentas lutas entre o Império Persa e o Império Otomano. O apogeu da Pérsia verificar-se-á a partir do final do séc. XVI,

5 Cf. António Dias FARINHA - Os portugueses no Golfo Pérsico, 1507-1538: contribuição documental e crítica para a sua história. Mare Liberum, 3, 1991; João Manuel de Almeida Teles e CUNHA - Economia de um império: economia política do Estado da Índia em torno do Mar Arábico e Golfo Pérsico: elementos conjunturais: 1595-1635, FCSH-UNL: Policopiada (diss. Mestrado), 1995.

6 Veja-se, como exemplo, FERRONHA, António Luís (coord.)-O confronto do olhar: o encontro dos povos na época das navegações portuguesas séculos XV e XVI: Portugal, África, Ásia, América, Lisboa: Caminho, 1991.

7 Cf. COSTA, Helder Santos - Da Pérsia moderna ao Irão Pahlavi. Lisboa: U.T.L./ /I.S.C.S.P./Centro de Estudos Islâmicos, 2005, p. 29-38. 
com a ascensão ao trono do Xeque Abbas I, responsável pela queda da Ormuz portuguesa em 1622, conjuntamente com forças inglesas ${ }^{8}$.

A luta contra o otomano demonstrou ser um ponto fundamental da política persa, ao longo de todo o séc. XVI. Destacamos a decisiva batalha de Chaldiran, em 1514, onde o exército otomano, equipado com forte artilharia, esmagou a cavalaria persa, pouco (ou nada) habituada a equipamento tão potente. $\mathrm{O}$ impacto desta batalha terá sido enorme e terá sido até o momento de afirmação do Império Otomano perante o Oriente e o Ocidente. Em 1516/17, o Egipto Mameluco cairia sob as forças otomanas, passando então a controlar todas as vias de comércio, desde o Mar Roxo, ao Levante e até as caravanas da famosa «rota da seda». As campanhas que se seguiram vieram afectar ainda mais o domínio persa no Oriente - em 1534/35, o (actual) Iraque cai nas mãos otomanas9. Para além destes tempos, o Império dos Xás manteve-se em forte actividade, até à queda da dinastia Safávida, no século XVIII.

D. Manuel I e Afonso de Albuquerque compreenderam a importância estratégica do reino persa, visto que dominava dois importantes empórios: Bassorá e Ormuz ${ }^{10}$. A primeira apresentava-se como cidade fundamental pela sua ligação à Europa através das cáfilas entre o Golfo Pérsico e o Mediterrâneo; por sua vez, Ormuz afirmava-se com um porto fulcral no comércio com a própria península indiana. Não era apenas um mercado riquíssimo, mas também um escoadouro das mercadorias do Guzerate, principalmente de Cambaia e Diu. Ao conquistar esta cidade, os portugueses pretendiam precisamente ter o controlo sobre as suas «opulentas correntes

8 Veja-se a recente obra de Dejanirah COUTO e Rui Manuel LOUREIRO - Ormuz 1507 e 1622. Conquista e perda. Lisboa: Tribuna da História, 2007.

9 Para todas estas questões veja-se GODINHO, Vitorino Magalhães - Os descobrimentos e a economia mundial. Lisboa: Editorial Presença, $2^{\mathrm{a}}$ ed., 1987, vol. III, p.111-112, 122-126; BACQUÉ-GRAMMONT, Jean-Louis - L'apogée de l'Empire ottoman: les événements (1512-1606) in MANTRAN, Robert (dir.) - Histoire de l'Empire Ottoman, Paris: Fayard, 1989, p.139-158.

${ }^{10}$ Sobre Ormuz, veja-se o estudo de Jean AUBIN - «Le royaume d'Ormuz au début $\mathrm{du} \mathrm{XVI}^{\mathrm{e}}$ siècle» in Le latin et l'astrolabe: recherché sur le Portugal de la Renaissance, son expansion en Asie et les relations internationales, vol. II. Lisboa/Paris: CNCDP/FCG, 2000; para uma sólida visão sobre o Golfo Pérsico, leia-se Willem FLOOR - The Persian Gulf: a political and economic history of five port cities, 1500-1730. Washington: Mage Publishers, 2006 
mercantis» ${ }^{11}$. Assim, os lusos não tardaram em estabelecer relações diplomáticas com o Sufi.

\section{As relações diplomáticas entre Portugal e a Pérsia nos alvores de Quinhentos}

O primeiro contacto "oficial" entre Portugal e a Pérsia teve por base a conquista portuguesa de Ormuz em 1507, pela armada de Albuquerque ${ }^{12}$.

Após a conquista desta cidade, o capitão-mor teve a notícia da presença de um capitão persa pronto a receber o pagamento das páreas que o reino de Ormuz "oferecia" anualmente ao Xeque. Albuquerque, naturalmente, não pretendia manter essa obrigação, uma vez que a ilha se encontrava, agora, sob jurisdição portuguesa e mandou dizer ao capitão que «[...] aquelle Reyno de Ormuz era del Rey de Portugal, ganhado com sua armada, e gente [...] e mandou trazer das naos pelouros de bombardas, bestas, e espingardas, e bombas de fogo: e que dissesse ao Rey, que mandasse tudo aquillo ao Capitão do Xeque Ismael, porque aquella era a moeda, em que El Rey de Portugal mandava aos seus Capitães, que lhe pagassem as pareas daquelle Reyno, que estava debaixo do seu senhorio, e mando» ${ }^{13}$. Pretendia, obviamente, impressioná-lo e dissuadi-lo de qualquer afronta.

Esta não era, no entanto, a melhor abordagem face a um Império tão poderoso e tão necessário aos interesses portugueses. Entenda-se que D. Manuel enquadrava a Pérsia no seu plano imperial. Concretizando, a ideologia manuelina previa a queda do Império Mameluco através de uma acção conjugada: Afonso de Albuquerque esforçar-se-ia para atacar através do Mar Roxo (até ao Cairo, passando então a ter o domínio sobre

${ }^{11}$ GODINHO, Vitorino Magalhães - Os descobrimentos e a economia..., cit., p. 124. Sobre a descrição destas cidades e das vias de Bassorá e da Pérsia, veja-se o estudo de SANTOS, João Marinho dos - Os portugueses em viagem: representações quinhentistas de cidades e vilas. Lisboa: GGTMECDP, 1996, p. 148-172.

${ }^{12}$ Cf. COUTO, Dejanirah e LOUREIRO, Rui Manuel - Ormuz ..., cit., p. 33-45.

${ }^{13}$ ALBUQUERQUE, Brás de - Comentários do grande Afonso de Albuquerque, capitam geral que foy das Indias orientaes, em tempo do muito poderoso Rey dom Manuel, o primeiro deste nome. Em Lisboa: por João de Barreira impressor del Rey, 1576, Parte I, cap. XL, fl. 97. 
esta via comercial); o Preste João atacaria pelo Sul, Carlos V e D. Manuel pressionariam através do Mediterrâneo (e no caso português, até avançando pelo Norte de África); e por fim, o Xeque Ismael investiria sobre o Sultão pelo Este ${ }^{14}$. As cartas de Albuquerque, enviadas ao Xá da Pérsia, propõem esta mesma estratégia: «[...] e porque eu tenho sabido que elle he vosso imiguo e vos faz guerra, vos mando esta nova, e vos offereço contra elle minha pessoa e armada del Rei nosso senhor pera ho ajudar a destruyr e ser contra elle cada vez que me pera isso requererdes; [...] e querendo o vós destruir per terra, podereis ter del Rei nosso senhor grande ajuda $d$ armada per mar, e creo que com mui pouco trabalho senhoreareis seu Reino e cidade do cayro e toda a sua terra e senhorio» ${ }^{15}$.

Após a conquista de Ormuz, três embaixadas portuguesas foram enviadas ao Xeque.

A primeira remonta a 1510, tendo como representante português junto do Xá, Rui Gomes de Carvalhosa. Levando um extenso regimento, não chegou a sair de Ormuz, pois foi envenenado por ordem de Cojeatar, governador da ilha ${ }^{16}$ (tendo em conta a reduzida comitiva, não existia ninguém para o substituir nas suas funções).

Sucumbindo a tal ataque, a embaixada desfez-se e ter-se-ia de esperar até 1513 para outro enviado ser eleito por Albuquerque. Desta vez, o governador enviou Miguel Ferreira como embaixador ${ }^{17}$ e João Ferreira como sota-embaixador, evitando assim que o acidente de 1510 se repetisse ${ }^{18}$. Recebido pelo Xeque com grande entusiasmo, Miguel Ferreira observou

${ }^{14}$ Cf. o estudo de THOMAZ, Luís Filipe - L’idée impériale manuéline in AUBIN, Jean (ed.) - La decouverte, le Portugal et l'Europe. Actes du colloque. Paris: FCG-CCP, 1990.

${ }^{15}$ «Carta d Afonso d Albuquerque, capitão e governador da India ao Xeque Ismael, Rei das carapuças Roxas» in PATO, Raymundo António de Bulhão (dir.) - Cartas de Affonso de Albuquerque seguidas de documentos que as elucidam, Lisboa: Academia Real das Sciencias de Lisboa, 1884-1935, vol. I, p. 388 - de seguida, esta obra essencial será apenas referida como $C A A$, e identificando o volume e a(s) página(s) correspondente(s).

${ }^{16} \mathrm{O}$ regimento encontra-se transcrito em $C A A$, II, p. 79-83; o triste desfecho é narrado (entre outros) por ALBUQUERQUE, Brás de - Comentários..., cit., Parte II, Cap. XXIII.

${ }^{17}$ Sobre o percurso de Miguel Ferreira, veja-se o estudo de FLORES, Jorge Manuel «Um homem que tem muito crédito naquelas partes»: Miguel Ferreira, os «Alevantados» do Coromandel e o Estado da Índia. Mare Liberum, 5 (Julho de 1993) 21-37.

${ }^{18}$ Veja-se o relato em CORREIA, Gaspar - Lendas da Índia, Lisboa: Academia Real das Sciencias de Lisboa, 1860, vol. II, p. 410-417; citaremos, de seguida, esta obra apenas por Lendas da Índia. 
todo o grande aparato da cidade de Tabriz e da vida na Pérsia. O líder persa firmou um "acordo" amigável com o governador português, dando asas ao (já referido) projecto de D. Manuel.

Regressado a Ormuz em 1515, após a conquista definitiva da cidade, o embaixador português encontrou-se com o governador. Decidido a enviar outra embaixada, Fernão Gomes de Lemos foi o escolhido, acompanhado de Gil Simões, escrivão ${ }^{19}$. Ao contrário do que aconteceu com Miguel Ferreira, as negociações não foram tão simples: a presença portuguesa em Ormuz não era bem vista pelo Sufi, já que implicava uma perda de poder na região do Golfo Pérsico, pois já não tinha controlo sobre o porto que orientava o comércio dessa região. Além deste pequeno contratempo, os enviados não tiveram qualquer outro tipo de problema, mas aquando do regresso a território português, o Leão do Mar não se encontrava vivo. Com a morte de Albuquerque, o ideal imperial do monarca português decaía, pois este era o seu grande executor "in loco".

As questões relativas a Ormuz mantiveram-se e foram responsáveis pela quarta embaixada, datada de 1523. Além do próprio rei de Ormuz se manifestar contra o pagamento de um tributo ao monarca português, o Xá continuava a não aceitar totalmente a subjugação da ilha às forças lusas, levando a que um dos seus capitães começasse a impedir que mantimentos e diversos produtos chegassem à cidade. De forma a resolver este impasse (sobretudo o bloqueio à ilha) Balthazar Pessoa foi enviado com uma vintena de acompanhantes, entre eles, António Tenreiro, autor de um Itinerário daquela viagem. A morte do grande Xeque Ismael deu-se precisamente aquando da presença portuguesa. Num clima de insegurança, a embaixada foi despachada sem qualquer resolução para o seu problema, pelo novo Xeque (Tamás).

Estas foram as embaixadas enviadas no período que é objecto da nossa análise. Posteriormente, a embaixada de Henrique de Macedo (em 1549) e

${ }^{19} \mathrm{O}$ relato completo desta embaixada encontra-se na Biblioteca da Ajuda (Lisboa) Códice 50-V-21, fl. 137v a 155r, dado a conhecer por SMITH, Ronald Bishop - The first age of the Portuguese embassies, navigations and peregrinations in Persia (1507-1524). Maryland: Decatur Press, 1970, p. 39-56. Duas cópias incompletas podem ser encontradas nas $C A A$, I, p. 391-394; II, p. 233-250. Encontramo-nos actualmente a preparar a publicação da cópia completa presente na Biblioteca da Ajuda. 
de Miguel d'Abreu de Lima (1572) ${ }^{20}$ encerram o ciclo de relações "directas" com a Pérsia, tendo em conta que as missões seguintes se encontram enquadradas no período da união dinástica, cuja política face às terras dos Sufi reflecte interesses diferentes ${ }^{21}$.

Os relatos das diversas embaixadas mencionadas vêm demonstrar que um novo mundo se abria aos portugueses, distinto do mundo Ocidental, onde «os homens são diferentes, a sua organização política e social não segue os padrões europeus, as práticas sociais são manifestamente outras» ${ }^{22}$.

\section{A civilidade persa aos olhos dos portugueses}

Norbert Elias, autor da obra O Processo Civilizacional, aprofundou largamente este tema, demonstrando que «courtoisie, civilité e civilisation marcam três fases de uma evolução social», sendo que a civilidade tem como marco as primeiras décadas do século XVI - em especial, a partir da obra de Erasmo de Roterdão, De civilitate morum puerilium, de 1530; a civilização só se afirmará posteriormente, a partir do séc. XVIII. Coincidindo com os nossos objectivos, a «[...] verdadeira mudança de comportamento nas camadas superiores e a formação de modelos de comportamento» ${ }^{23}$ verifica-se nesta fase intermédia.

As mudanças ocorridas nesta época são várias, já que «[...] as coacções exteriores se transformam em autocoacções, como as funções fisiológicas

${ }^{20}$ Acerca das relações com a Pérsia no reinado de D. Sebastião, veja-se LOUREIRO, Francisco de Sales - O enquadramento europeu de uma Embaixada Portuguesa à Pérsia. Arquivos do Centro Cultural Português, XI (1977) 491-506.

${ }^{21}$ Cf. GULBENKIAN, Roberto - As embaixadas e as Missões diplomáticas portuguesas na Pérsia. Anais da Academia Portuguesa da História, II Série, 31 (1986) 485-506.

${ }^{22}$ LOUREIRO, Rui-O encontro de Portugal com a Ásia no século XVI in FERRONHA, Luís (coord.) - O confronto do olhar: o encontro dos povos na época das navegações portuguesas, séculos XV e XVI: Portugal, África, Ásia, América. Lisboa: Editorial Caminho, 1991, p. 167.

${ }^{23}$ Para todas, cf. ELIAS, Norbert - O processo civilizacional: investigações sociogenéticas e psicogenéticas, Lisboa: Publicações D. Quixote, 2006, 2a ed., p. 209. É necessário notar que este estudo (de 1939) encontrou-se praticamente ignorado até a sua tradução inglesa de 1969; para uma visão de conjunto sobre a obra deste sociólogo alemão veja-se GOUDSBLOM, Johan e MENNELL, Stephen - The Norbert Elias Reader, [s.1.]: Blackwell Publishers, 1997. 
são, de forma cada vez mais diferenciada, deslocadas para trás dos bastidores da vida social e envoltas em sentimentos de vergonha, como a regulamentação de toda a vida pulsional e afectiva se torna cada vez mais abrangente, uniforme e estável, graças a um constante autocontrolo» ${ }^{24}$.

Assim, pretendemos abordar a problemática da civilidade, captada pessoalmente ou ouvida ou lida no Oriente pelos portugueses. No entanto, não nos esqueçamos que esta visão focava o "outro", o "diferente", que se distinguia pelos seus usos e costumes, pois estes não se identificavam com os conhecidos no "Ocidente". Aliás, e seguindo as linhas da antropologia cultural, é necessário conhecer o princípio do relativismo cultural, ou seja, que «[... $]$ os juízos de valor baseiam-se na experiência, e esta é interpretada por cada indivíduo em termos da sua própria endoculturação» ${ }^{25}$, sem esquecer que «[...] a posição relativista não significa, de forma alguma, que todos os sistemas de valores, todos os conceitos, de bem e de mal, assentem sobre areias tão movediças que não haja necessidade de uma moral, de formas de comportamento estabelecidas e aceitas, de códigos éticos» ${ }^{26}$. Na maior parte dos casos, estes hábitos diferentes «[...] não podem ser entendidos como algo de "negativo", como "falta de civilização" ou de "saber" (como facilmente temos tendência a julgar), mas como algo que correspondia às necessidades daquelas pessoas e se lhes afigurava razoável e necessário exactamente na forma que revestia» ${ }^{27}$.

\subsection{Os regimentos das embaixadas}

Não podemos deixar de fazer referência aos diversos regimentos dirigidos às várias embaixadas que contactaram com o Xeque Ismael. A preocupação do respeito pelo outro, índice da civilidade portuguesa, encontra-se aí espelhada. No regimento que levava Miguel Ferreira, o governador mandava-lhe

${ }^{24}$ ELIAS, Norbert - O processo..., cit., p. 620.

${ }^{25}$ LIMA, Augusto Mesquitela [et al] - Introdução à antropologia cultural. Lisboa: Editorial Presença, 1980, 2a ed., p. 61. Sobre este tema, veja-se também Enciclopédia Einaudi, dir. Ruggiero ROMANO, vol. 38: Sociedade-Civilização, Lisboa: IN-CM, 1999, entradas «Aculturação» e «Selvagem/bárbaro/civilizado» da autoria de Ignacy Sachs

${ }^{26}$ LIMA, Augusto Mesquitela Lima [et al] - Introdução à antropologia ..., cit., p. 62.

${ }^{27}$ ELIAS, Norbert - O processo..., cit., pp-162-163. 
que «[...] nunqua risse de cousa que visse, $[\ldots]$ e que de cousa boa nem má que visse se espantasse, nem se pusesse a olhar, [...] e do que lhe perguntassem se era boa qualquer cousa que lhe perguntassem, dissesse que si; [...] e que nom cospisse estando fallando com homens que o visitassem $»^{28}$. Tanto este regimento, como o da embaixada seguinte apresentam muitos outros aspectos que não cabem aqui discutir, como a obrigação de procurarem alguma presença cristã nos locais pelos quais passariam, ou a obrigação de demonstrarem serem impiedosos (de forma a vincar o carácter implacável português).

\section{2. $\mathrm{O}$ banquete $\mathrm{e} o$ estar à mesa}

Nas diversas embaixadas enviadas à Pérsia, o banquete sempre revelou ser um momento de destaque, onde os portugueses observavam e entravam num rito diferente do habitual. Nos casos de Fernão Gomes de Lemos e Balthazar Pessoa, os relatos das viagens apresentam características bem curiosas.

Desde já, estes banquetes eram momentos solenes, ricos, espelho da grandeza do arraial do Sufi. Eram grandes festas com «[...] muitas diversidades de manjares, e fruitas, e vinhos e muitos tangeres darpas, alaudes e frautas á nosa husança» $»^{29}$, em que estava «[...] a mesa chea de iguoarias» ${ }^{30}$. Por exemplo, «as iguarias que se derão geralmente forão carneiro, e arroz guizado de muitas cores: a saber, preto, branco, amarello, e outras mais cores, tortas, e malassadas de ovos com açúcar por sima, pão de trigo feito á maneira de bolos muito delgados $»^{31}$. No início do banquete oferecido a Fernão Gomes de Lemos, decorrido após todos os homens de armas presentes no campo terem comido, o Xeque lavou as mãos numa bacia, limpando-as

${ }^{28}$ Lendas da Índia, p. 357.

${ }^{29}$ CAA, II, p. 236.

${ }^{30}$ CAA, II, p. 238.

${ }^{31}$ TENREIRO, António - «Itinerário de António Tenrreyro...» in Itinerários da Índia a Portugal por Terra, rev. e pref. António Baião, Coimbra: Imprensa da Universidade, 1923, p. 35-36. Esta obra será referida, doravante, apenas como Itinerário. 
de seguida - sem dúvida um indício de civilidade, pois encontramos esta regra nos manuais de civilidade ocidentais do séc. XVI ${ }^{32}$.

Largas referências são feitas acerca do consumo exagerado do vinho nestes banquetes, assunto deveras interessante. Como já foi referido pelo investigador Rudi Matthee, desde a antiguidade que o império persa denotava um interesse particular pelo vinho ${ }^{33}$. A chegada da nova religião veio alterar os hábitos, já que esta proibia o consumo de vinho. Veja-se o Alcorão: «Ó vós que credes! As bebidas inebriantes, os jogos de azar, a dedicação às pedras e a adivinhação com setas são abominações provenientes da actividade de Satanás. Evitai-a!» ${ }^{34}$. O vinho era, então, reprimido no Islão, mas pelo observado, não o era na Pérsia Safávida.

A corte do Xeque Ismael era grande consumidora deste produto, não fazendo qualquer embargo ao seu uso. Aliás, as vésperas da batalha de Chaldiran terão sido ocupadas por extenso banquete com largo consumo de vinho (talvez para combater o medo do combate), factor decisivo na própria condução da batalha ${ }^{35}$. A vitória dos otomanos terá levado o Xeque a um desleixo perante a governação do império, e a refugiar-se em banquetes, entregando-se ao vinho e aos prazeres da carne $^{36}$.

Regressando às nossas embaixadas, encontramos o vinho como principal figura num banquete. Em Portugal (e no caso europeu no geral), encontramos indícios de um uso menor e mais leve, pois «tem-se a impressão de que, desde o começo do século XV, pelo menos, ninguém que se prezasse gostava de ser apodado de bom bebedor. Outros tempos, outro conceito do homem ${ }^{37}$.

$\mathrm{O}$ banquete dado pelo Xeque aquando da embaixada de Fernão Gomes de Lemos, em 1515, apresenta uma vivência relevante. O próprio monarca

${ }^{32}$ Cf. ELIAS, Norbert - O processo..., cit., p. 188; e REVEL, Jacques - Les usages de la civilité in ARIÈS, Philippe e DUBY, Georges (dir.) - Histoire de la vie privée: 3. De la Renaissance aux Lumières. Paris: Seuil, 1999, p. 167-208.

${ }^{33}$ MATTHEE, Rudi - The pursuit of pleasure. Drugs and stimulants in Iranian history, 1500-1900. Washington: Mage Publishers, 2005, p. 37-38.

${ }^{34}$ Alcorão. Mem-Martins: SporPress, 2002, Sura V: 90-91 ; veja-se na mesma obra, Sura II: 218.

${ }^{35}$ MATTHEE, Rudi - The pursuit..., cit., p.- 49-50.

${ }^{36}$ Cf. MATTHEE, Rudi - The pursuit..., cit., p. 50.

${ }^{37}$ ARNAUT, Salvador Dias - A arte de comer em Portugal na Idade Média in $O$ "Livro de Cozinha" da Infanta D. Maria de Portugal. Coimbra: Por ordem da Universidade, 1967, p. LII. Veja-se também as páginas LXII a LIV. 
persa tomou especial atenção ao consumo de vinho pelos portugueses nesse dito banquete, já que «[...] the mandou dar huma arredoma de vinho de peras que he o milhor que la há» ${ }^{38}$. A insistência em faze-los beber comprova a importância dessa bebida nestes ritos. O mesmo governador do Xeque afirmava que «[...] por força os fazia beber, e asi a elles porque hum capitão andava bradando e quasi espancando a quem não bebia, que por força aviam de beber as taças cheas e sem agoa» ${ }^{39}$.

Esta referência ao traçar do vinho com água é fundamental, já que este hábito era recorrente em Portugal (e, regra geral, no Ocidente em si). O objectivo era claro: diminuir os seus efeitos, moderar o beber. Já os monarcas portugueses o faziam e aconselhavam, visto que «[...] podemos suspeitar que D. João I normalmente terçava de água o vinho, quanto a D. Duarte podemos dizer que ia mais longe: duas partes de água e uma de vinho $»^{40}$. O filho do rei de Boa Memória deixou no seu Leal Conselheiro o aviso de que «o vinho, se o bever, seja razoadamente augado, porque se é forte, dá maior trabalho ao estamago em no cozer e degerir, e acrecenta sede, per que nom se pode bem soportar com pouco bever» ${ }^{41}$. $\mathrm{O}$ vinho bebido "em bruto" simbolizava um maior domínio do corpo, por parte daquele que o bebia, daí este hábito se ter enraizado na Pérsia. Mais tarde, António Tenreiro notará que «muito se espantou o governador [persa], que nos convidou, do embaixador, e portuguezes deitarem agoa no vinho» ${ }^{42}$ aquando de um banquete dado em Xiras.

O controlo que os nossos portugueses possuíam perante o consumo do vinho pressupunha uma consciência face aos seus efeitos. Restringir os comportamentos e as atitudes era um preceito necessário aos homens de armas portugueses no Oriente: na obra Primor e Honra da Vida Soldadesca no Estado da Índia, o autor (anónimo) afirma que «[...] convem aos capitães, e pessoas de conselho não serem boquirrotos, nem se tomarem do vinho; porque deixando a parte os desconcertos e desatinos, que a bebidice tras

${ }^{38}$ CAA, II, p. 238.

${ }^{39}$ CAA, II, p. 238.

${ }^{40}$ ARNAUT, Salvador Dias - A arte de comer..., cit., p. LI.

${ }^{41}$ D. Duarte, Leal Conselheiro. Lisboa: Imprensa Nacional-Casa da Moeda, 1999, c. C, p. 367 .

${ }^{42}$ Itinerário, p. 19. 
comsigo facilmente faz descubrir tudo o que està no peito ensarrado, e escondido, $[\ldots]$ alem disto fara commeter cousas desiguaes e temerárias $\rangle^{43}$.

No entanto, não nos fiquemos por aí. Voltando ao banquete de Fernão Gomes de Lemos, «[...] cada vez que lhes davam de beber amostravam as taças ao Xeque, e se não eram muito cheas mandavalhe deitar mais, e elle [o Xeque] bebia por huma taça de pedra encastoada em ouro que levaria meia canada $^{44},[\ldots]$ e amostrava aos nosos cada vez que bebia a taça, dizendo que soo bebia mais que elles todos» ${ }^{45}$. Não poderia deixar de referir o pequeno desafio lançado pelo monarca persa: o enviado português terá posto em causa a sua firmeza e a sua virilidade ao suspeitar que este bebia tanto pelo vinho ser aguado, «[...] pelo qual o Xeque lhe mandou dar o porcelana porque bebia chea, na qual o embaixador descançou tres veses» ${ }^{46}$ para conseguir beber tudo!

Nestes banquetes, registados pelas nossas fontes, era característico fazer-se algum tipo de homenagem, de troca de presentes, já num estado avançado de embriaguez, com certeza, como sinal da boa hospitalidade e do bem-estar dos convidados naquele momento. No caso que temos vindo a referir, a embaixada portuguesa recebeu roupas persas, e o governador do Xeque vestiu roupa portuguesa: «[...] poz huma carapuça de velludo na cabeça, que the deu o embaixador com huma estampa douro, e huma figura que o Xeque perguntou que era, dise o enbaixador que era Santiago ${ }^{47}$. Tenreiro encontrará também tal costume aquando da sua viagem (como veremos mais à frente).

Se o relato de Gil Simões, escrivão da embaixada de 1515, é particularmente interessante, o itinerário resultante da embaixada de 1523, vem confirmar estas práticas.

Na descrição da cidade de Xirás, Tenreiro descreve muito bem esta prática, onde descreve um típico banquete, entrando nos moldes descritos

${ }^{43}$ Primor e Honra da Vida Soldadesca no Estado da Índia. Em Lisboa: Por Jorge Rodrigues, 1630, II ${ }^{a}$ Parte, c. X, fl.61v; para uma edição actualizada veja-se Laura Monteiro PEREIRA (introd., elucidário e glossário) - Primor e honra da vida soldadesca no Estado da Índia. Ericeira: Mar das Letras Editora, 2003.

${ }^{44}$ Cerca de $0,75 \mathrm{~L}$.

${ }^{45}$ CAA, II, p. 238.

${ }^{46} C A A$, II, p. 238.

${ }^{47} C A A$, II, p. 239. 
anteriormente por Gil Simões, onde começando o consumo pela manhã, mantêm-se assim até à meia noite, ou mesmo até de madrugada, «[...] até que se enbebedão não céssão de beber e sempre anda o copeyro em roda viva deytando vinho» ${ }^{48}$. A troca de presentes também esteve presente, e após um já largo consumo, em que se «[...] começão a esquentar do vinho, se alevantão em pé, e se fazem grandes reverencias hum ao outro, e cada hum bebe hũa grande taça de vinho, que levará hũa boa çumicha, e se tornão a assentar, e tornão a beber por outra taça mais pequena $»^{49}$. Estando próximos de um consumo quase caótico, dá-se a troca de trajes em que «[...] o convidador despe alli o convidado dos vestidos que tem, e lhe veste o vestido, que the dá, e lhe cinge a espada rica» ${ }^{50}$.

O festim oferecido pelo Xeque Ismael apresenta um ambiente bem mais festivo do que em 1515. Realizado numa gigantesca tenda, de forma a albergar todos os grandes do reino ${ }^{51}$, o monarca persa detinha (como seria de esperar) uma posição de destaque, e diante de si «[...] garrafas de ouro, e de prata com turquezas, e rubîs em ellas encastoados, em vasos de ouro, por que bebia» ${ }^{52}$. Noutro dia, continuando-se os grandes festejos, Tenreiro denota então uma suposta tradição persa, reveladora do gosto pelo vinho por este povo, já que informa ser «costume antigo dos reys da Persia, que quanto mais bebião sem se embebedar, tanto mais estimados erão» ${ }^{53}$. Claro está, e de forma a concluir as descrições do autor, este observou que «[...] o Sufi bebeo por vezes do vinho da porcelana, mas de todas ellas pouca moça fazia. [...] E no tempo que andamos neste arrayal os mais dos dias vinham muitos mouros e mouras Persianos em magotes [...] e logo por lhes fazer muito honra e gasalhado a esta gente [o Xeque] bebia perante eles huma taça de vinho ${ }^{54}$.

${ }^{48}$ Itinerário, p. 18.

${ }^{49}$ Itinerário, p. 19.

${ }^{50}$ Itinerário, p. 19.

${ }^{51}$ Esta tenda seria uma segunda residência do Xeque, um autêntico palácio montável em qualquer parte. Tenreiro informa-nos que «as mezas que estavão pera as ilhargas no campo tomarião de espaço a cada parte dous tiros de bésta» (Itinerário, p. 35), ou seja, cerca de $400 \mathrm{~m}$.

${ }^{52}$ Itinerário, p. 35.

${ }^{53}$ Itinerário, p. 38.

${ }^{54}$ Itinerário, p. 38. 
Como pudemos então observar, o vinho fazia parte do quotidiano e dos rituais persas de hospitalidade. No entanto, este vício não se encontraria alargado a toda a população, mas apenas às classes superiores da sociedade. Podemos, claro, pôr em causa a atitude do monarca, já que deveria honrar e respeitar as leis islâmicas. No entanto, se entendermos a concepção do seu poder, ou seja, advindo de ordem sagrada, um murchid (um chefe espiritual em que Deus encarna), então este não precisaria de evitar o vinho, já que não comete (ou tem) pecados, e não necessita dessa restrição. O seu sucessor, o Xeque Tamás, apresentava inicialmente o mesmo vício que o pai, e quem o diz é o próprio Tenreiro, pois num dos banquetes identifica-o, sendo «[...] hum filho [do Sufi], que ahi tinha de idade de dezaseis anos, o continuava mais, e bebia tambem como seu pay» ${ }^{55}$. No entanto, após um conturbado período, este novo monarca proibiu estritamente o consumo do vinho, com o seu famoso Édito de Sincero Arrependimento, datado de 1532-33. As próprias fontes persas afirmam que após tal acto, Tamás nunca mais terá consumido vinho ${ }^{56}$.

\subsection{A violência e a insegurança}

Não foi em vão que João de Barros afirmou, acerca do Xeque Ismael, que «[... este principe [...] éra terror da Pérsia» ${ }^{57}$. São várias as fontes que demonstram a crueza e o ímpeto do monarca persa. $\mathrm{O}$ seu próprio império era composto por uma sociedade guerreira, habituada às lides do campo de batalha. No fundo, e tal como Norbert Elias afirmava para o mundo medieval ocidental, «a alegria em torturar e matar outros era grande e era uma alegria socialmente permitida. Em certa medida, a organização social até impelia nesse sentido, tornando necessário ou fazendo parecer conveniente esse tipo de comportamento ${ }^{58}$. Além do mais, não existia um poder central que

${ }^{55}$ Itinerário, p. 36.

${ }^{56}$ Cf. MATTHEE, Rudi - The pursuit..., cit., p. 50.

${ }^{57}$ BARROS, João de - Ásia de João de Barros dos feitos que os portugueses fizeram no descobrimento e conquista dos mares e terras do oriente. Lisboa: por Germão Galharde, 1553, Segunda Década, Livro Décimo, c. IV, fl. 134v.

${ }^{58}$ ELIAS, Norbert - O processo..., cit., p. 323. 
pudesse cercear esses comportamentos agressivos, pois quando estes existem (como começa a acontecer na Europa do séc. XVI), «[...] não é qualquer indivíduo que, por ser forte, pode dar-se ao prazer de agredir fisicamente, mas apenas uns poucos que são legitimados pelo poder central, como é o caso da polícia» ${ }^{59}$. O que acontece no Ocidente é sobretudo uma moderação dos comportamentos através da criação de uma "consciência colectiva" capaz de repreender este tipo de conduta mais "bárbara".

Nos diversos relatos existentes, por várias vezes os autores nos informam de lugares que foram arrasados pelo Xá, por não se submeterem ao seu poder. Se Fernão Gomes de Lemos nos informa que a cidade de Carmaça, «[...] ja fora muy gramde cidade o quall o Xeque Ismaell destroyo porque se alevamtou comtra elle» ${ }^{60}$, António Tenreiro dá-nos conta da cidade de Espayão, e do facto de que o Xeque «[...] veio sobre elle com grande exercito, e o destruhio, e assim a toda a terra, e comarca. E dentro em a dita Cidade fez grandes cruezas, e mandou atar muitos mouros como carneiros, e deitar no chão pés com cabeça, e depois o proprio Sufi com duas espadas, ou treçados, cada hũa em sua mão, de cada golpe os matava, e cortava a huns os pés, a outros mãos» ${ }^{61}$.

A violência por parte do monarca não se fazia sentir apenas para com os outros. Aquando da embaixada de 1513, o embaixador português (Miguel Ferreira) adoeceu gravemente de peçonha, envenenado por um escravo, sendo responsável pela paragem da viagem durante três meses, de forma a este recuperar. Ao saber do sucedido, o monarca persa revelou grande preocupação, e mandou que o embaixador fosse levado numa espécie de maca, com grande cuidado, ameaçando de morte toda a comitiva caso este não sobrevivesse à viagem ${ }^{62}$. Chegou até a encarregar o seu físico-mor de tratar o português, e caso este não o curasse, cortar-lhe-ia a cabeça ${ }^{63}$ !

As constantes referências às forças militares do Xeque, sobretudo quantificando-as, revela bem o carácter bélico da sua comitiva, e da atenção dada pelos portugueses a estes pormenores.

\footnotetext{
${ }^{59}$ ELIAS, Norbert - O processo..., cit., p. 333.

${ }^{60}$ Biblioteca da Ajuda (Lisboa) - Códice 50-V-21, fl. 140v.

${ }^{61}$ Itinerário, p. 21.

${ }^{62}$ Lendas da Índia, p. 411.

${ }^{63}$ ALBUQUERQUE, Brás de - Comentários ..., cit., Parte IV, c. XIX, p. 471.
} 
A vivência da caça pelo monarca persa é um tema recorrente dos relatos das embaixadas. De facto, quer no Ocidente, quer no Oriente, a caça sempre foi uma actividade ligada ao acto da violência, fosse em termos meramente recreativos, ou até como treino militar, servindo de preparação para a guerra. Enquanto em Portugal surgiam as chamadas matas reais ${ }^{64}$, a Pérsia possuía um método diferente de caça - sempre o teve, pois já as fontes da antiguidade referem campos cerrados para esta actividade. As três embaixadas (1513, 1515 e 1523) observaram momentos de caça, bem diferentes dos nossos, nomeadamente pela violência no acto de matar, e por serem realizadas numa espécie de recinto fechado (ao modo mongol ${ }^{65}$ ).

Exemplifiquemos: na embaixada de Miguel Ferreira, este pôde assinalar no seu relato uma ida à caça. Conjuntamente com muita gente (sem definir um número certo), o Xeque acompanhava a marcha a partir de um andor, levado sobre os ombros. Chegando a um grande campo, o monarca ordenava o seu fecho, isto é, a colocação de homens à sua volta, avançando para o centro, cercando-o, e empurrando assim os animais para a zona central, mandando de seguida largar os cães. Numa segunda fase, mandou abrir o campo, e aí, a «[...] gente de cavallo que as corressem [os animais], e matassem com suas lanças, e arcos com frechas, que correndo vão tirando ${ }^{66}$. Largadas depois as onças domesticadas, o cenário de caça não apresentava grandes momentos de violência, face àqueles que presenciou e participou o seguinte embaixador, Fernão Gomes de Lemos.

A descrição dessa nova viagem apresenta essa vivência nos mesmos moldes que o anterior. O monarca terá mandado cercar três a quatro léguas de terra. Haveria aí «[...] até mil e quinhentas cabeças de animalias, a saber, veados, carneiros, bodes, e cabras bravas, e usos, adibes, e lobos e porcos $\rangle^{67}$. Entrando o Sufi nesse terreno tão "rico", começou a usar o arco, trespassando três animais de cada vez, e cansado dessa arma, «[...] tomou huum trecado e começou acutilar nellas, e dava golpe que fendia huma animalia da cabeça até o rabo em maneira que caia huma parte a huum cabo, e outra a outro,

${ }^{64}$ Cf. COELHO, Maria Helena da Cruz e RILEY, Carlos Guilherme - Sobre a caça medieval. Estudos Medievais. 9 (1988) 221-267.

${ }^{65}$ COUTO, Dejanirah e LOUREIRO, Rui Manuel - Ormuz..., cit., p. 47.

${ }^{66}$ Lendas da Índia, p. 416.

${ }^{67}$ CAA, II, p. 241. 
e asi partia outras através ${ }^{68}{ }^{6}$. Farto de tal, deu então ordens para os seus homens avançarem, gabando-se posteriormente, ao nosso embaixador, de num Inverno ter morto em Sau, vinte mil animais, e noutro Inverno, 52 mil $^{69}$ em Espão ${ }^{70}$.

Nesta mesma linha, encontramos a existência de um "alcoram", entre Carma e Caixão, um monumento feito de «[...] cabeças de veados e carneiros e bodes bravos e doutros muytos alymarias que hy [o Xeque] matou hum inverno ${ }^{71}$, uma espécie de pequena torre, simbolizando o poder e a violência do monarca. Posteriormente, António Tenreiro dará conta destes mesmos "alcoram", mas chamando-lhes "curichéo" («[...] todo feito de cabeças, e cáveiras de veados assim como parede» ${ }^{72}$ ), e até de outros, edificados «[...] de todas as cabeças das alimárias, que alli matavão» ${ }^{73}$.

Mantendo-nos na descrição de António Tenreiro, nesse mesmo capítulo o autor caracteriza as caçadas do Xeque. Divergindo dos relatos anteriores, este afirma que eram feitas junto a serras, de forma a ter apenas que cercar três lados, visto que os animais não conseguiam subir mais. O modo de operação não diferia: entrar e matar.

A insegurança presente ao longo da estrada não escapou aos olhos portugueses. Na viagem da segunda embaixada encontramos uma comitiva de sessenta frecheiros à procura do enviado persa, visto que este era esperado por parentes de alguns ladrões que tinha mandado enforcar, de forma a vingarem-se ${ }^{74}$. O escrito da embaixada de Balthazar Pessoa apresenta vários casos, como por exemplo a existência de «[...] fortalezas, castellos roqueiros, e cisternas de agoa chovediça. Servem estas fortalezas, e castellos pera se acolherem os moradores a ellas, quando sentem ladrões que os vem a roubar» $»^{75}$, ou o facto de que «[...] em muitos passos deste caminho tivemos

${ }^{68}$ CAA, II, p. 241.

${ }^{69}$ A leitura deste número nas $C A A$ encontra-se mal feita - são 52 mil e não apenas 7 mil, conforme se pode ler no manuscrito da Biblioteca da Ajuda (Lisboa) - Códice 20-V-21, fl. $147 \mathrm{v}$.

${ }^{70}$ Cf. CAA, II, p. 241.

${ }^{71}$ Biblioteca da Ajuda (Lisboa) - Códice 50-V-21, fl. 141r.

72 Itinerário, p. 22.

${ }^{73}$ Itinerário, p. 23.

${ }^{74}$ CAA, II, 235.

${ }^{75}$ Itinerário, p. 12. 
grande arreceio de ladrões, e porque se ajuntou com o Embaixador grande recova de mouros, levávamos dez, ou doze espingardeiros Portuguezes, nunca nos ousarão cometer ${ }^{76}$.

Esta violência constante (ou perigo de) apresenta uma Pérsia com uns contornos ainda muito pouco civilizados, comparando com os que o mundo Ocidental apresentaria posteriormente. Mas, naquele momento, que visão teriam os portugueses sobre os seus comportamentos, sobre a sua própria violência? Sem dúvida que a força usada em vários actos bélicos demonstra que os portugueses pretendiam impor-se, e demonstrar a sua força através das armas. O vice-rei D. Francisco de Almeida, aquando da sua ida para Diu, em 1509 (onde a famosa batalha aconteceria), parou em Dabul, provocando uma autêntica razia, e onde «[...] o mayór estrágo que ouve delles, foy na mesquita e á própria pórta de cada hum defendendo filhos e molher, de cujos córpos as ruas ficáram juncadas: em que ouve mais de mil e quinhentos segundo se depois contaram ${ }^{77}$. Afonso de Albuquerque sabia também ser um inimigo implacável - ele próprio afirmava a D. Manuel que «[...] nenhuma sepultura nem edifício de mouros não deixo em pé; os que agora tomam vivos, mando-os assar; tomaram aqui um arrenegado, e mandei-o queimar» ${ }^{78}$. Esta própria violência enquadrava-se na estratégia portuguesa de «impressionar e dissuadir até aterrorizar» ${ }^{79}$ o outro.

Como acabámos de ver, a violência não era factor unicamente persa, mas sim comum a todos os povos. A civilidade vem alterar esta concepção e este uso da força, pois é «no decurso do processo de civilização [que] os homens procuram reprimir tudo o que em si próprios sentem como tendo “carácter animal" $\gg{ }^{80}$, nomeadamente estas manifestações de agressividade.

\footnotetext{
${ }^{76}$ Itinerário, p. 20.

${ }^{77}$ BARROS, João de - Ásia ..., Segunda Década, Livro Terceiro, c. IV, fl. 37v.

${ }^{78}$ Apud SANTOS, João Marinho dos - A guerra e as guerras na expansão portuguesa (séculos XV e XVI). Lisboa: GTMECDP, 1998, p. 273.

${ }^{79}$ Cf. SANTOS, João Marinho dos - A guerra e as guerras ..., cit., p. 269-274.

${ }^{80}$ ELIAS, Norbert - O processo..., cit., p. 230.
} 


\subsection{A corte como centro difusor (ou não) de civilidade}

Como sabemos, a corte portuguesa no século XVI é já uma corte "moderna", dentro do processo civilizacional, ou seja, um centro que irradia civilidade, sobretudo a partir daqueles que aí residem e/ou convivem. Num Portugal que domina os mares, a corte é ocupada pela nobreza (que tem interesse em submeter-se ao poder do rei) e pela burguesia mercantil (que se afirma pela riqueza e procura fazer jus à honra, através de serviços prestados e reconhecidos). A proximidade ao monarca/príncipe define o estatuto e o prestígio dentro da corte, e impõe um modelo de virtudes necessário ao cortesão.

A abertura cultural da corte àquilo que chega, quer dos restantes reinos europeus, quer dos territórios do além-mar, influencia as vivências dos cortesãos, dos governantes e, em última instância, de sectores da sociedade que se vão transformando por estas novidades. A nova nobreza «directamente ou por interposta pessoa, entra no tráfico marítimo, em todo o comércio com as regiões mais longínquas do Globo» ${ }^{81}$, pelo que altera os seus comportamentos até as suas condutas. Garcia de Resende registou esta mudança na sua Miscelânea: «[...] non lhes lembrava tractar,/nem muyto negociar:/eram com pouco contentes,/ com amigos, e parentes/ costumavam de folgar./ Depois foram tam polidos,/ tam ricos, tam atilados,/ tam doces, e tal luzidos,/ e tam cheos desmaltados,/ cabelleiras, e tingidos,/ e em gastar desordenados,/ e tantos trajos mudados,/ tanto mudar de viver,/ tanto tractar, revolver,/ tanto ser negociados ${ }^{82}$. Consequentemente, a própria alteração da corte será referida por este autor quinhentista, visto que «[...] vimos bem pequena ser,/ depois tanto ennobrescer» ${ }^{83}$, chegando aos seus cinco mil moradores, «[...] a que el Rey dá assentamentos,/ moradias, casamentos,/ tenças, merces, e honores» ${ }^{84}$.

A existência desta proximidade entre nobre/mercador, e até de alguma sobreposição nas funções e cargos (que encontramos patente na ascensão

${ }^{81}$ GODINHO, Vitorino Magalhães - Estrutura da antiga sociedade portuguesa. Lisboa: Arcádia: 1975, 2 ed., p. 90-91.

${ }^{82}$ RESENDE, Garcia de - «Miscelânea» ..., cit., p. 369.

${ }^{83}$ RESENDE, Garcia de - «Miscelânea» ..., cit., p. 377.

${ }^{84}$ RESENDE, Garcia de - «Miscelânea» ..., cit., p. 377. 
social de alguns membros da corte), apresenta um modelo diferente daquele que as fontes portuguesas transmitem sobre a Pérsia - onde esta sobreposição entre nobre e mercador não era tão visível.

Documentemos: ao chegar a Tabriz em 1513, Miguel Ferreira observa a grandiosidade desta cidade. Sede do Império Persa ${ }^{85}$, o embaixador português regista que a corte aí presente era composta pela nobreza de guerra, pois «[...] os capitães sempre estavão na côrte com El Rey» ${ }^{86}$. No palácio real, o embaixador passou por «[...] huma grande sala onde estava nobre gente», o que reforça a ideia de que a nobreza dominava a corte. Uma passagem da descrição de Gil Simões, onde refere o conflito entre o Sufi e o Império Otomano, reitera esse mesmo distanciamento social entre nobres e mercadores: «[...] ao xeque foy notefiquado a ida do turquo, o qual não quiz crer, dizendo como avia de crer que huum mercador avia de ser cavalleiro» ${ }^{87}$.

Ora, não existindo essa inter-relação e essa mobilidade social tão características da Europa da Época Moderna, a corte persa opera a civilidade de um modo bem diferente. Esta não irradia, não é projectada, e pode até nem servir de modelo à restante sociedade. É, portanto, uma corte mais fechada, decorrente da impossibilidade de ascensão.

Ao invés, a proximidade com a corte portuguesa dá-se pela sua itinerância. Em Portugal, ainda durante grande parte do século XVI a corte movia-se por vários pólos (apesar de Lisboa ser já considerada primeira cidade do reino). Esta itinerância, de carácter administrativo, aumentava os encargos, e talvez até facilitava a irradiação de um modelo de comportamento através das suas deslocações pelo território. A itinerância persa era muito superior e de carácter guerreiro. As deslocações eram feitas consoante a proximidade com o palco de guerra. Os arraiais que o Xá montava eram grandiosos locais de convívio para toda a corte, em que «[...] averya XXXb [trinta e cinco mil] tendas porque o campo que era muy comprido e largo era tudo cheo dellas e averya pasamte de C [cem mil] de cavallo e XXXb ou R [quarenta

${ }^{85}$ Gil Simões, na embaixada de Fernão Gomes de Lemos, afirmaria que «[...] o xeque Ismael nella faz seu continuo estar, por ser ali grande muito farta»-CAA, II, p. 249.

${ }^{86}$ Lendas da Índia, p. 411.

${ }^{87}$ CAA, II, p. 244. 
mil] molheres» ${ }^{88}$. A descrição de António Tenreiro corrobora a «extremada riqueza» destes arraiais e destas tendas ${ }^{89}$. No entanto, este testemunho dános a conhecer uma certa proximidade dos mercadores. Explicitemos: estes teriam um arraial próprio, afastado do arraial régio, «[...] em que andão muitos mercadores que trazem todos mercadorias $\rangle^{90}$, chamado de ordubuzar, parecendo uma feira, e responsável pelo abastecimento do arraial do Sufi.

Esta próxima convivência encontrar-se-ia, então, a meio caminho entre a realidade portuguesa (com cavaleiros-mercadores e mercadores enobrecidos) e o rigoroso sistema de castas da península do industão (impedindo qualquer tipo de mobilidade social, e o afastamento entre os membros destas mesmas castas).

\section{Conclusão}

Que conclusões retirar desta breve abordagem às terras do Xá? Que civilidade existia na Pérsia aos olhos dos portugueses? Tentámos esboçar tal realidade nas páginas anteriores, recorrendo aos mais diversos exemplos encontrados em textos da época.

Alguns indícios de civilidade (como era entendida na Europa) podem aí ser encontrados, mas não em tão larga escala como no Ocidente. Este é um processo que pressupõe uma «[...] alteração do comportamento e da sensibilidade humana numa direcção muito definida»" ${ }^{11}$, onde «[...] cada indivíduo é forçado a ponderar melhor o efeito das suas acções ou das acções de outros sobre toda uma série de elos da cadeia social» ${ }^{92}$.

Portugal viи e оиviu as formas de pensar, de sentir e de agir do outro, tentando compreendê-las e enquadrá-las. Os textos que nos chegaram demonstram bem estas ideias, de interpretar o que parecia estranho, e de integrar estas novidades «nos parâmetros culturais ocidentais»,

\footnotetext{
${ }^{88}$ Biblioteca da Ajuda (Lisboa) - Códice 50-V-21, fl. 141v.

${ }^{89}$ Itinerário, p. 34-40.

${ }^{90}$ Itinerário, p. 40.

${ }^{91}$ ELIAS, Norbert - O processo..., cit., p. 619.

${ }^{92}$ ELIAS, Norbert - O processo..., cit., p. 626.
} 
incorporando-os «na visão do mundo europeia» ${ }^{93}$. Os autores dos textos aqui analisados tentaram sempre encontrar alguma relação com os seus conhecimentos que possuíam do mundo Ocidental, isto é, referentes, que os ajudassem a caracterizar, classificar e compreender o mundo Oriental. É nesse sentido que Tomé Pires afirma que os habitantes de Tabriz e Xirás são «[...] como em framça paris sam domesticos gemtijs homens cortesãos» ${ }^{94}$, ou Gil Simões identifica os georgianos com carapuças «[...] a feyçam de gorras framcessas ${ }^{95}$, ou ainda Duarte Barbosa identifica que além dos manjares dos habitantes de Ormuz nomeados, há ainda «[...] todas outras cousas que há em Espanha» ${ }^{96}$, ou (para finalizar) António Tenreiro ao informar que quanto ao trajar do povo de Tabriz, «[...] trazem lenços finos de cores acolchoados, com capas de pannos de Londres $\rangle^{97}$. Os textos procuravam sempre encontrar uma ligação e um termo de comparação entre o novo e o antigo.

Sem dúvida os portugueses de quinhentos deram novos mundos ao mundo, e procuraram ultrapassar as barreiras culturais existentes, consolidando as relações entre os povos. No fundo, Portugal levou consigo a civilidade europeia, e contribuiu para o processo civilizacional (nos moldes em que Norbert Elias o definiu) no Oriente, sobrepondo-o àquele que já aí existiria.

${ }^{93}$ LOUREIRO, Rui - O encontro de Portugal com a Ásia ..., cit., p. 165.

${ }^{94}$ PIRES, Tomé - A suma oriental de Tomé Pires in CORTESÃO, Armando (ed.) - A suma oriental de Tomé Pires e o livro de Francisco Rodrigues. Coimbra: por ordem da Universidade, 1978, p. 151.

${ }^{95}$ Biblioteca da Ajuda (Lisboa) - Códice 50-V-21, fl.142r e 143v.

${ }^{96}$ BARBOSA, Duarte - Livro do Oriente de Duarte Barbosa in Além-Mar. Códice Casanatense 1889 com o Livro do Oriente de Duarte Barbosa. Lisboa: Bertrand, 1984, p. 54.

${ }^{97}$ Itinerário, p. 30. 


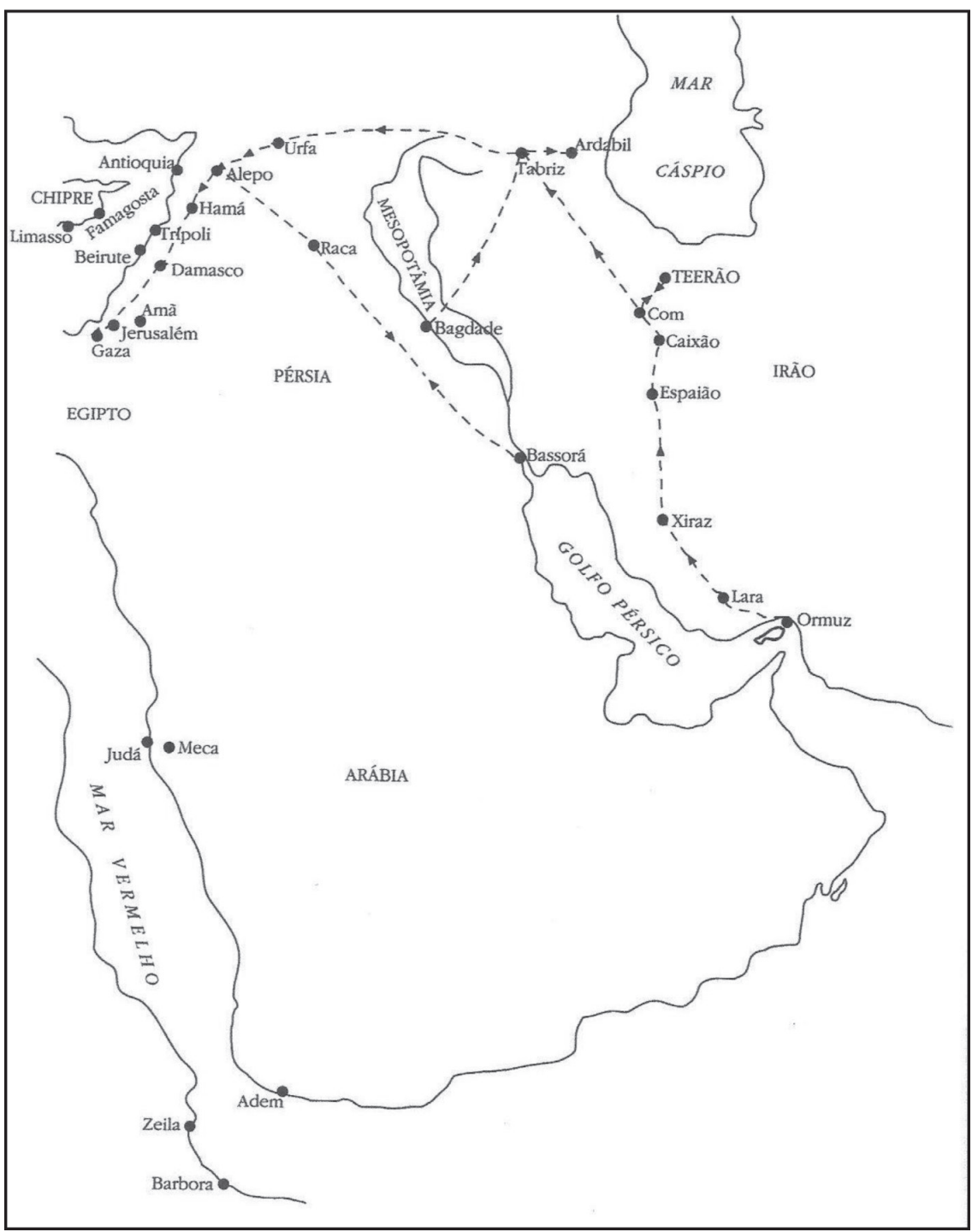

As vias de Bassorá e da Pérsia

In SANTOS, João Marinho dos - Os portugueses em viagem pelo mundo: representações quinhentistas de cidades e vilas, Lisboa: GTMECDP, 1996, p. 158. 


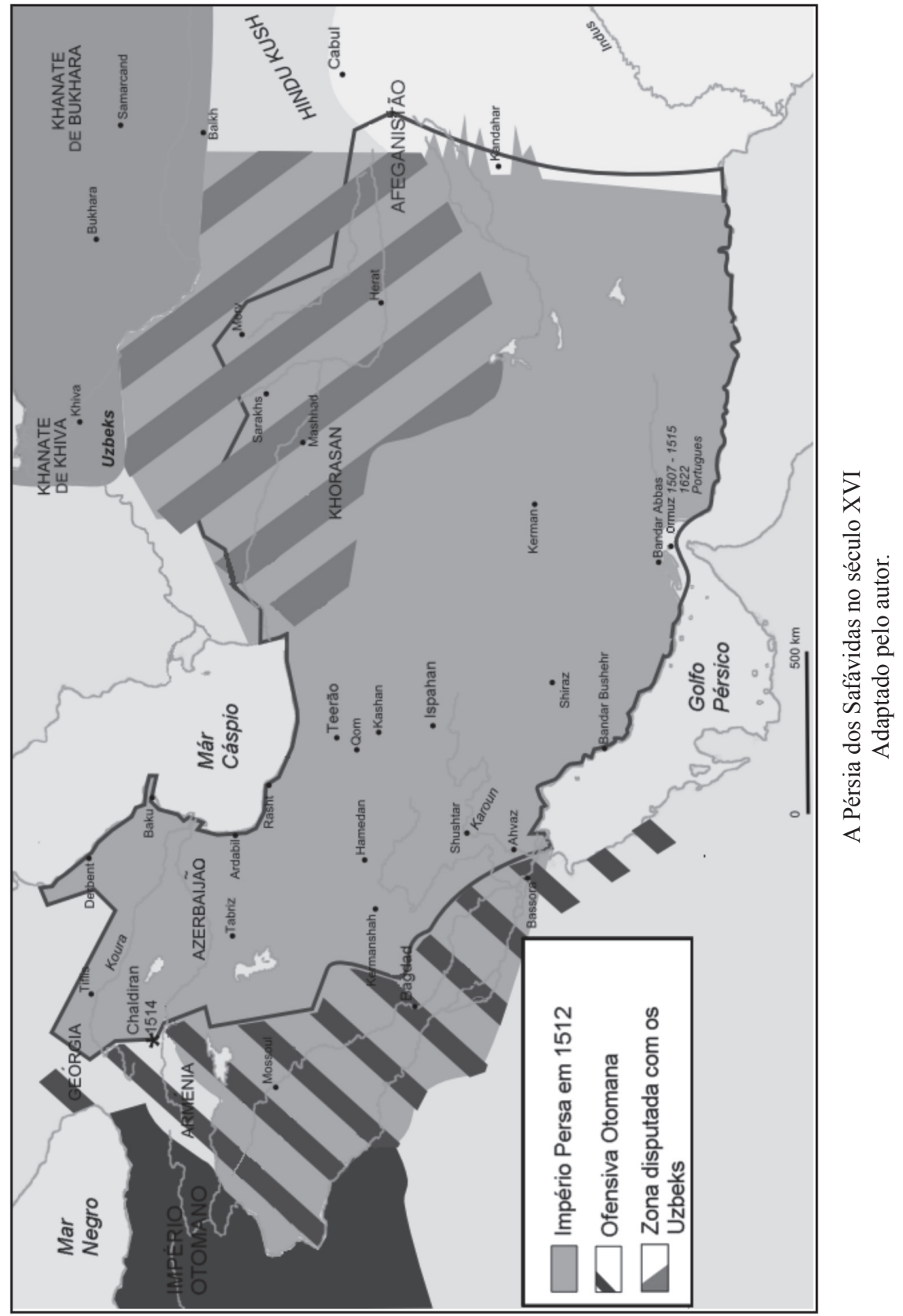

